\title{
Respons Pertumbuhan Tanaman Mentimun (Cucumis sativus) terhadap Pemberian Unsur Hara Fermentasi Buah Pepaya (Carica papaya)
}

\author{
Ita Emilia $^{1 *}$, Dewi Novianti ${ }^{2}$, Marmaini ${ }^{3}$, Dian Mutiara ${ }^{4}$ \\ *e-mail: itaemilia742@gmail.com \\ 1,2,3,4 Program Studi Biologi, Fakultas Sains dan Teknologi \\ Universitas PGRI Palembang
}

\begin{abstract}
The Research on Growth Responses of Cucumber (Cucumis sativus) to Fermented Papaya (Carica papaya) nutrients carried out at the Workshop of the Faculty of Science and Technology, University of PGRI Palembang, aimed at assessing the response to the application of organic nutrient concentrations of fermented papaya on height, stem diameter and number of leaves on the vegetative growth of cucumber plants for four weeks. The study used the RAL method, namely the provision of organic nutrients fermented papaya fruit with six different concentrations. The results of the research showed that there was a significant effect of the treatment on the three observed cucumber plant growth parameters. The P5 treatment $(500 \mathrm{ml} / \mathrm{L})$ resulted in the highest value of $55.4 \mathrm{~cm}$ plant height, 18.32 leaf number and $0.98 \mathrm{~cm}$ plant stem diameter, which were significantly different from other treatments.
\end{abstract}

Keywords: nutrients, growth, cucumber, papaya fruit

\begin{abstract}
ABSTRAK
Penelitian Respons Pertumbuhan Tanaman Mentimun (Cucumis sativus) Terhadap Pemberian Unsur Hara Fermentasi Buah Pepaya (Carica papaya) telah dilakukan di Workshop Fakultas Sains dan Teknologi Universitas PGRI Palembang, bertujuan mengkaji respons pemberian konsentrasi unsur hara organik fermentasi buah pepaya pada tinggi, diameter batang dan jumlah daun pada pertumbuhan vegetatif tanaman mentimun selama empat minggu. Penelitian menggunakan metode RAL yaitu pemberian unsur hara organik fermentasi buah pepaya dengan enam konsentrasi yang berbeda. Hasil ansira penelitian menunjukkan adanya pengaruh nyata perlakuan terhadap tiga parameter pertumbuhan tanaman mentimun yang diamati. Perlakuan $\mathrm{P}_{5}$ $(500 \mathrm{ml} / \mathrm{L})$ menghasilkan nilai tertinggi yaitu $55,4 \mathrm{~cm}$ tinggi tanaman, jumlah daun 18,32 helai dan diameter batang tanaman yaitu $0,98 \mathrm{~cm}$ berbeda nyata dengan perlakuan lainnya.
\end{abstract}

Kata Kunci: unsur hara, pertumbuhan, mentimun, buah pepaya

\section{PENDAHULUAN}

Buah mentimun (Cucumis sativus L.) adalah salah satu tanaman yang tumbuh di Indonesia dan memiliki potensi antioksidan. Dalam uji pendahuluan (fitokimia) terhadap buah mentimun diperoleh jenis-jenis senyawa aktif, antara lain : senyawa alkaloid, fenolik, senyawa flavonoid, steroid, terpenoid, dan saponin (Agustin dan Gunawan, 2019). Mentimun merupakan buah yang kaya air, buah yang rendah kalori, sebagai sumber vitamin $\mathrm{C}$ dan adanya kandungan flavonoid yang mempunyai efek antioksidan, dengan 
cara memutus radikal bebas reaktif yang cenderung membentuk radikal baru. Mentimun termasuk ke dalam golongan buah yang di konsumsi untuk menurunkan tekanan darah karena mentimun mempunyai sifat hipotensif (Martini dan Christine, 2021). Mentimun mempunyai fungsi sebagai penyejuk kulit (Hamzah et al., 2012). Selain itu, mentimun juga bermanfaat sebagai anti kanker (Aziz et al., 2018). Hal ini dikarenakan kandungan senyawa dalam mentimun mengandung tanin yang merupakan senyawa bersifat sitotoksik (Putra et al., 2019).

Produksi mentimun perlu ditingkatkan mengingat manfaat yang dimiliki oleh tanaman ini. Salah satu usaha agar produksi buah mentimun meningkat adalah melakukan intensifikasi penambahan unsur hara. Unsur hara diperlukan dalam proses pertumbuhan yang meliputi unsur hara mikro dan makro. Penambahan unsur hara dalam suatu media tanam bertujuan dalam pemenuhan kandungan unsur hara sehingga diperoleh hasil produksi yang lebih baik. Tanaman akan memberikan respons baik jika penambahan unsur hara dilakukan dengan cara yang sesuai dengan kebutuhan tanaman (Sihaloho et al., 2015). Pemberian unsur hara dapat meningkatkan pembentukan klorofil daun, mengkokohkan serta meningkatkan daya tahan tanaman mentimun dari terjadinya kekeringan (Fitriani et al., 2013).

Unsur hara cair merupakan unsur hara yang berbahan dasar dari tumbuhan dan hewan serta sudah mengalami proses fermentasi, berwujud cairan berisi kandungan senyawa kimia. Pada dasarnya unsur hara cair mempunyai keuntungan, yaitu dalam mengaplikasikannya mudah, selain itu unsur hara cair lebih mudah diserap oleh tanaman, banyaknya kandungan mikroorganisme, mengatasi penurunan (defisiensi) hara, mampu secara cepat menyediakan unsur hara, waktu pembuatannya lebih cepat, yang paling penting dalam pertanian penerapannya lebih mudah, yaitu saat penyemprotannya dapat langsung ke tanaman tersebut (Siboro, 2013).

Menurut Syahputriani (2017) unsur hara dapat dibuat dari buah pepaya yang tidak layak dikonsumsi. Masyarakat banyak mengkonsumsi buah papaya karena selain bergizi tinggi, pepaya mudah diolah, mudah diperoleh dan memiliki harga yang terjangkau. Buah pepaya memiliki tekstur yang lembut sehingga mudah rusak dan dalam jangka lama tidak tahan jika disimpan. Buah pepaya yang matang tidak langsung habis terjual sehingga sering mengalami pembusukan dapat menimbulkan masalah dalam lingkungan. Buah pepaya mempunyai kelebihan, yaitu dapat dibuat menjadi unsur hara dalam membantu meningkatkan nutrisi bagi pertumbuhan suatu tanaman. Unsur hara organik cair yang berbahan baku buah pepaya terdiri dari karbohidrat, $\mathrm{K}, \mathrm{Ca}$, $\mathrm{Mg}, \mathrm{Fe}$ dan fosfor yang tinggi, sehingga sangat baik untuk pertumbuhan serta perkembangan mikroorganisme dan tanaman.

Mubarok et al. (2019), menjelaskan penambahan unsur hara organik cair yang berasal dari pepaya terhadap produktivitas mentimun dengan konsentrasi $90 \mathrm{ml} /$ liter berpengaruh nyata meningkatkan tinggi tanaman mencapai $27,34 \mathrm{~cm}$, panjang buah mentimun 24,27 $\mathrm{cm}$, diameter buah mentimun $5,01 \mathrm{~cm}$, jumlah buah mentimun pertanaman 20 buah, terdapat jumlah buah per plot 118 buah, dan buah mentimun memeiliki berat 7816,87 gram, selama 2 bulan.

Penambahan bio aktivator EM4 (Effective Microorganisme) dalam pembuatan pupuk organik cair, khususnya dari limbah buah-buahan bertujuan untuk meningkatkan kandungan nitrogen, pospor, dan kalium sebagai unsur hara makro bagi tanaman. 
Namun, terlebih dulu ditambahkan bahan organik yang berupa pupuk organik ke dalam tanah agar penggunaan EM4 akan lebih efisien. EM4 mempercepat terjadinya proses fermentasi bahan organic, sehingga memudahkan dalam penyerapan unsur hara. Selain itu, EM4 efektif sebagai pestisida hayati dan bermanfaat dalam meningkatkan mutu tanaman Selain itu, kelebihan Effective Microorganisme ini merupakan bahan yang dapat mempercepat pembentukan pupuk organik serta meningkatkan kualitasnya, struktur tanah menjadi lebih baik setelah diberi EM4 sehingga menyuplai unsur hara yang dperlukan tanaman (Meriatna et al., 2018). Latar belakang diatas membuat penulis terdorong untuk mengkaji respons pertumbuhan tanaman mentimun (Cucumis sativus) terhadap pemberian unsur hara fermentasi buah pepaya (Carica papaya).

\section{BAHAN DAN METODE}

Pelaksanaan penelitian ini di Workshop Fakultas Sains dan Teknologi UPGRI Palembang. Adapun alat-alat yang dipakai dalam penelitian ini : jangka sorong, timbangan analitik, gelas ukur, batang pengaduk, ember, polybag ukuran $3 \mathrm{~kg}$, kamera, saringan, bak semai, alat tulis, dan kertas label. Bahan meliputi : benih tanaman mentimun (Cucumis sativus), limbah pepaya (Carica papaya), air, EM4, tanah dan gula pasir.

Metode dalam penelitian ini metode eksperimen Rancangan Acak Lengkap (RAL), terdiri dari 6 macam perlakuan dan 4 kali ulangan Perlakuan diberikan sebagai berikut:

$$
\begin{aligned}
& \mathrm{P} 0=\text { Kontrol (tanpa unsur hara) } \\
& \mathrm{P} 1=100 \mathrm{ml} / \mathrm{L} \text { unsur hara pepaya } \\
& \mathrm{P} 2=200 \mathrm{ml} / \mathrm{L} \text { unsur hara pepaya } \\
& \mathrm{P} 3=300 \mathrm{ml} / \mathrm{L} \text { unsur hara pepaya } \\
& \mathrm{P} 4=400 \mathrm{ml} / \mathrm{L} \text { unsur hara pepaya }
\end{aligned}
$$

$\mathrm{P} 5=500 \mathrm{ml} / \mathrm{L}$ unsur hara papaya

Penentuan tata letak unit percobaan yang dilakukan dengan cara pengundian.

\section{Prosedur Kerja}

\section{Pembuatan Unsur Hara Buah Pepaya}

Sebanyak 5 kg Pepaya dicincang menggunakan pisau sampai menjadi potongan kecil lebih kurang $1 \mathrm{~cm}$. Setelah itu, disiapkan air (5 liter) dimasukkan ke ember, diberi 100 gram gula pasir, diaduk hingga larut. Selanjutnya tambahkan $100 \mathrm{ml}$ EM. Ember harus ditutup rapat dan diletakkan terhindar dari cahaya matahari. Setelah 2 minggu, dilakukan penyaringan untuk memisahkan ampas dan unsur hara pepaya (Parintak, 2018).

\section{Pemilihan Benih Mentimun (Cucumis sativus)}

Benih mentimun yang digunakan yaitu benih yang memiliki viabilitas $85 \%$. Agar kulit benih menjadi lunak dilakukan perendaman benih (selama \pm 15 menit) dengan tujuan mempercepat pertumbuhan benih. Benih yang terapung disisihkan, benih yang terendam akan digunakan untuk ditanam.

\section{Persemaian}

Sebelum ditanam, benih disemai terlebih dahulu dalam bak persemaian yang sudah ada media tanah. Benih disemai selama 2 minggu, setelah itu bibit yang mempunyai 2 helai daun dipindahkan ke polybag.

\section{Persiapan Media Tanam}

Polybag yang diperlukan berukuran $2 \mathrm{~kg}$ sebanyak 24 buah dan masing-masing diisi $2 \mathrm{~kg}$ tanah. Media tanam mentimun diolah diberi unsur hara sesuai dengan perlakuan dan dibuat 2 minggu sebelum bibit mentimun dipindahkan ke dalam polybag dan disusun sesuai dengan tata letak unit percobaan. 


\section{Penanaman}

Pemilihan bibit yang akan
ditanam yaitu bibit yang telah mempunyai 2 helai daun agar pertumbuhan seragam dan dipindahkan ke media tanam dalam polybag. Sebelum bibit ditanam, media tanam disiram air terlebih dahulu. Untuk menghindari terjadinya penguapan yang berlebihan , pemindahan bibit dilakukan pada pagi hari. Saat penanaman bibit, media dalam polybag diberi lubang terdalam $3 \mathrm{~cm}$ (Oviyanti et al., 2016).

\section{Perlakuan}

Pemberian unsur hara buah pepaya yang terdiri dari 5 taraf konsentrasi berikut : $0 ; 100 \mathrm{ml} / \mathrm{L} ; 200$ $\mathrm{ml} / \mathrm{L} ; 300 \mathrm{ml} / \mathrm{L} ; 400 \mathrm{ml} / \mathrm{L} ; 500 \mathrm{ml} / \mathrm{L}$. Setiap perlakuan diulang sebanyak 4 kali. Aplikasi unsur hara buah pepaya dilaksanakan saat tanaman mentimun berumur 1 hingga 4 minggu setelah tanam, dengan interval waktu 1 minggu sekali dengan disiramkan ke media tanam.

\section{Pemeliharaan}

Pemeliharaan tanaman mentimun yaitu dilakukan penyiraman yang dilakukan pagi hari serta sore hari, atau disesuaikan dengan kondisi lapangan.

\section{Pengamatan}

Selama 4 minggu sejak tanaman dipindahkan ke polybag dilakukan pengamatan, dengan interval 1 minggu sekali untuk melihat pertumbuhan tanaman mentimun meliputi jumlah daun, tinggi tanaman, dan diameter batang.

\section{Parameter yang Diamati}

Parameter yang diamati meliputi :

a. Tinggi tanaman $(\mathrm{cm})$ yang diukur mulai dari pangkal batang sampai dengan ujung daun terpanjang. Pengamatan satu minggu sekali, yaitu saat umur 7 hst; 14 hst; 21 hst; 28 hst. b. Jumlah daun (helai) dilakukan dengan cara menghitung jumlah daun yang sudah terbuka secara sempurna dengan interval waktu 1 minggu sekali.

c. Diameter Batang $(\mathrm{cm})$ diukur dengan mempergunakan kalifer atau jangka sorong pada bagian batang bawah yaitu $5 \mathrm{~cm}$ dari pangkal batang.

\section{Pengumpulan dan Analisis Data}

Data dianalisis menggunakan analisis sidik ragam (Tabel 1. ANSIRA). Seandainya perlakuan berpengaruh nyata maka dilanjutkan dengan Uji BNT (Uji Beda Nyata Terkecil, dengan taraf $\mathrm{a}=5$ $\%)$.

\section{HASIL DAN PEMBAHASAN}

Hasil penelitian pemberian unsur hara fermentasi buah pepaya (Carica papaya) terhadap tinggi tanaman mentimun (Carica papaya) dilakukan analisis sidik ragam didapatkan Fhitung lebih besar daripada Ftabel 5\%. Hasil BNT pada Tabel 1 berikut.

Tabel 1. Hasil Uji BNT Respons Tinggi Tanaman Mentimun

\begin{tabular}{crc}
\hline Perlakuan & Tinggi Tanaman (cm) \\
\hline P0 & 20,3 & $\mathrm{a}$ \\
P1 & 31,2 & $\mathrm{~b}$ \\
P2 & 37,6 & $\mathrm{c}$ \\
P3 & 43,1 & $\mathrm{~d}$ \\
P4 & 49,2 & $\mathrm{e}$ \\
P5 & 55,4 & $\mathrm{f}$ \\
\hline \multicolumn{4}{c}{ BNT 5\%=5,42 }
\end{tabular}

Keterangan: Rata-rata yang diikuti oleh huruf sama artinya berbeda tidak nyata

Tabel 1, perlakuan berbagai konsentrasi perlakuan pemberian unsur hara fermentasi buah pepaya berbeda nyata terhadap tinggi tanaman mentimun disemua perlakuan. Hasil dari perlakuan tertinggi untuk parameter pertumbuhan tinggi tanaman mentimun yaitu pada perlakuan $\mathrm{P}_{5} \quad(500 \mathrm{ml} / \mathrm{L}$ unsur hara 
fermentasi buah pepaya) dengan nilai rata - rata tinggi mentimun $55,4 \mathrm{~cm}$ berbeda nyata terhadap semua perlakuan, sedangkan respons paling rendah pada perlakuan P0 (menggunakan air tanpa pemberian unsur hara fermentasi buah pepaya).

Syahputriani (2017), kandungan buah pepaya terdiri dari kalsium, karbohidrat, fosfor, kalium, magnesium, dan besi untuk diolah sebagai unsur hara bagi pertumbuhan tanaman. Konsentrasi unsur hara yang tinggi berkaitan dengan suplai air, nutrisi dan fotosintat akan meningkatkan pembelahan sel, pembesaran dan pengembangan sel pada batang tanaman (Gustia, 2016).

Secara statistik, perlakuan pemberian berbagai konsentrasi unsur hara fermentasi buah pepaya menunjukkan pengaruh nyata bagi pertumbuhan jumlah daun mentimun nilai Fhitungnya 52,42 besar dari Ftabel 2,77 pada $\alpha 5 \%$. Hasil Uji BNT dapat dilihat pada Tabel 2 .

Tabel 2. Respons Jumlah Daun Tanaman Mentimun

\begin{tabular}{crr}
\hline Perlakuan & \multicolumn{2}{c}{ Jumlah Daun (Helai) } \\
\hline P0 & 6,15 & $\mathrm{a}$ \\
P1 & 8,66 & $\mathrm{~b}$ \\
P2 & 11,53 & $\mathrm{c}$ \\
P3 & 13,21 & $\mathrm{~d}$ \\
P4 & 16,04 & $\mathrm{e}$ \\
P5 & 18,32 & $\mathrm{f}$ \\
\hline
\end{tabular}

Keterangan: Rata - rata yang diikuti oleh huruf yang sama artinya berbeda tidak nyata

Tabel 2 hasil uji BNT 5\% terlihat pada parameter jumlah daun pada perlakuan $\mathrm{P}_{0}$ berbeda nyata dengan perlakuan lainnya, begitu juga dengan perlakuan pada $\mathrm{P}_{1}, \mathrm{P}_{2}, \mathrm{P}_{3}, \mathrm{P}_{4}$ dan $\mathrm{P}_{5}$. Pemberian tertinggi untuk parameter pertumbuhan jumlah daun mentimun yaitu pada perlakuan $\mathrm{P}_{5}(500 \mathrm{~m} / \mathrm{L}$ unsur hara) dengan nilai rata-rata 18,32 helai. Pemberian konsentrasi unsur hara fermentasi buah pepaya menunjukkan peningkatan yang sangat signifikan terhadap jumlah daun seiring dengan peningkatan konsentrasi perlakuan yang diberikan.

Pertumbuhan diameter batang mentimun yang diberi perlakuan unsur hara buah pepaya selama 4 minggu didapatkan Fhitung 8,14 besar dari Ftabel 2,77 $\alpha 5 \%$. Hasil Uji BNT pada Tabel 3 berikut.

Tabel 3. Pertumbuhan Diameter Tanaman Mentimun

\begin{tabular}{ccc}
\hline Perlakuan & $\begin{array}{c}\text { Diameter Batang } \\
\text { (cm) }\end{array}$ \\
\hline P0 & $0,30 \quad \mathrm{a}$ \\
P1 & $0,42 \quad \mathrm{~b}$ \\
P2 & $0,58 \quad \mathrm{c}$ \\
P3 & $0,71 \quad \mathrm{~d}$ \\
P4 & $0,84 \quad \mathrm{e}$ \\
P5 & $0,98 \quad \mathrm{f}$ \\
\hline \multicolumn{2}{l}{ BNT 5\%=0,06 }
\end{tabular}

Keterangan: Rata-rata 1 yang diikuti oleh huruf yang sama artinya berbeda tidak nyata.

Tabel 3. semakin tinggi konsentrasi perlakuan pemberian unsur hara fermentasi buah pepaya maka semakin meningkat respons pertumbuhan diameter batang mentimun. Perlakuan Po menunjukkan rata-rata terendah karena $\mathrm{P}_{0}$ sebagai kontrol atau tanpa pemberian unsur hara sehingga kekurangan unsur hara yang dibutuhkan oleh mentimun, sedangkan pada perlakuan $\mathrm{P}_{5}(500 \mathrm{ml} / \mathrm{L}$ unsur hara buah pepaya) merupakan konsentrasi tertinggi untuk memenuhi kebutuhan unsur hara mentimun.

Buah pepaya yang difermentasi diolah menjadi pupuk organik mengandung unsur nitrogen yang mana unsur ini digunakan untuk pembentukan protein dan berbagai bahan penting lainnya, sintesis klorofil, sel-sel baru terbentuk sehingga menambah diameter batang mentimun. Posfor yang terdapat pada buah pepaya 
menstimulasi sistem perakaran sehingga fungsi akar dapat menyerap unsur hara lebih baik untuk pertambahan diameter batang. Masa vegetatif tanaman dimulai dari proses perkecambahan biji. Proses imbibisi kandungan air meningkat. Radikula merupakan stuktur pertama yang muncul, kemudian diikuti pembentukan jaringan dan organ seperti batang dan daun. Akar akan menyerap air, hara dan mineral di dalam tanah. Batang berperan memberi kekuatan dan menyokong tanaman, sedangkan daun berperan dalam pembentukan makanan melalui fotosintesis (Rizal et al 2019).

Pembuatan unsur hara fementasi buah pepaya menggunakan bioaktivator berupa EM4. EM4 merupakan campuran kultur berbagai mikroba yang bermanfaat bagi pertumbuhan tanaman, dapat digunakan sebagai sumber inokulum untuk meningkatkan keragaman dan populasi mikroba (Rahmah et al (2014). Hasil penelitian (Jalaluddin et al., 2016), semakin lama fermentasi dan semakin banyak konsentrasi EM4 yang digunakan maka semakin meningkat nilai $\mathrm{N}, \mathrm{P}$ dan $\mathrm{K}$ yang diperoleh pada pembuatan unsur hara pupuk organik. Nilai $\mathrm{pH}$ paling tinggi diperoleh pada lamanya waktu fermentasi selama 9 hari dengan volume EM4 sebanyak $40 \mathrm{ml}$ yaitu $\mathrm{pH} 6,89$. Konsentrasi $\mathrm{N}$ tertinggi yaitu $2,80 \%$ volume EM4 $70 \mathrm{ml}$ dengan waktu fermentasi 15 hari. Konsentrasi K sebesar $0,64 \%$ pada volume EM4 $70 \mathrm{ml}$ dengan lamanya waktu fermentasi 15 hari, konsentrasi $\mathrm{P} 1.16 \%$ pada volume EM4 $70 \mathrm{ml}$ dengan lama fermentasi 18 hari. Mikroorganisme fermentator di dalam EM4 berkisar 80 jenis. Lima mikrooranisme utama berupa bakteri fotosintetik, Streptomyces $\mathrm{sp}$ Lactobacillus sp, yeast, dan Actinomycetes. Nur et al (2016) menyatakan proses fermentasi terjadi dalam kondisi anaerobik, konsentrasi air sedang (30-40\%), konsentrasi gula tinggi, dan suhu sekitar $40-50^{\circ} \mathrm{C}$

\section{KESIMPULAN}

Pemberian unsur hara fermentasi bbuah pepaya memberikan pengaruh nyata terhadap pertumbuhan tanaman mentimun. Terjadi peningkatan pertumbuhan seiring konsentrasi perlakuan yang diberikan. Perlakuan P5 $(500 \mathrm{ml} / \mathrm{L}$ unsur hara buah pepaya) didapatkan nilai rata-rata tertinggi pada pertumbuhan tinggi tanaman yaitu 55,4 $\mathrm{cm}$, jumlah daunnya yaitu 18,32 helai dan diameter batangnya $0,98 \mathrm{~cm}$, sedangkan nilai rata - rata terendah yaitu pada perlakuan P0 tanpa pemberian unsur hara.

\section{DAFTAR PUSTAKA}

Agustin, V., S. Gunawan. 2019. Uji Fitokimia dan Aktivitas Antioksidan Ekstrak Mentimun (Cucumis sativus). Tarumanagara Medical Journal. 1 (2): 195-200.

Azis, Y. Abubakar, N. M. Erfiza. 2018. Analisis Total Flavonoid dan Vitamin C pada Beberapa Jenis Mentimun (Cucumis sativus L.). Jurnal lmiah Mahasiswa Pertanian Unsyiah. 3 (1): 381-387.

Fitriani, L., Toekidjo dan P. Setyastuti. 2013. Keragaman Lima Kultivar (Capsicum annum L.) Di Dataran Medium. Jurnal Vegetalika. 2(2): 50-63.

Gustia, H. 2016. Respons Pertumbuhan dan Produksi Tanaman Mentimun Terhadap Pemangkasan Pucuk. Proceedings. The 2nd International Multidisciplinary Conference 2016. Universitas Muhammadiyah Jakart. Jakarta. 339-345

Hamzah, H., Kunu, P.J., dan Rumakat, A. 2012. Respon Pertumbuhan dan Produksi Ketimun (Cucumis sativus L) Terhadap Sistem Pengolahan 
Tanah dan Jarak Tanam. Jurnal Agrologia. 1 (2): 106-112.

Jalaluddin, Nasrul Z, A., dan Rizki, S. 2016. Pengolahan Sampah Organik Buah- Buahan Menjadi Pupuk dengan Menggunakan Efektif Mikroorganisme. Jurnal Teknologi Kimia Unimal, 5 (1): 17-29.

Martini, M., M. Christine. 2021. Pengaruh Pemberian Jus Mentimun terhadap Tekanan Darah pada Lansia Hipertensi Di PSTW Sinta Rangkang Tahun 2020. Jurnal Keperawatan Stikes Suaka Insan. 6 (1): 53-58.

Meriatna, Suryati, A. Fahri. 2018. Pengaruh Waktu Fermentasi dan Volume Bio Aktivator EM4 (Effective Microorganisme) pada Pembuatan Pupuk Organik Cair (POC) dari Limbah Buah-Buahan. Jurnal Teknologi Kimia Unimal. 7 (1): 13-29.

Mubarok, R. F. A., B. Tripama, dan B. Suroso. 2019. Efikasi Pupuk Organik Cair (Poc) Buah Pepaya (Carica papaya L.) Terhadap Produktivitas Tanaman Mentimun (Cucumis sativus L.). Jurnal Agritrop. 17(1): 76 - 92.

Nur. T., A. R. Noor., dan M. Elma. 2016. Pembuatan Pupuk Organik Cair Dari Sampah Organik Rumah Tangga dengan Penambahan Bioaktivator EM4 (Effective Microorganisms). Konversi. 5(2): 5-12.

Oviyanti, F., S. Syarifah, N. Hidayah. 2016. Pengaruh Pemberian Pupuk Organik Cair Daun Gamal (Gliricidia Sepium (Jacq.) Kunth Ex Walp.) terhadap Pertumbuhan Tanaman Sawi (Brassica juncea L.). Jurnal Biota. 2(1): 61-67.

Parintak, R. 2018. Pengaruh Pemberian Pupuk Organik Cair dari Limbah Buah Pepaya dan Kulit Nanas Terhadap Pertumbuhan Kangkung
Darat (Ipomea reptans Poir). Skripsi. Universitas Sanata Dharma Yogyakarta.

Putra, K.A., I. Purwaningsih, Kuswiyanto. 2019. Oksisitas Akut Ekstrak Metanol Mentimun (Cucumis Sativus L.) terhadap Larva Artemia Salina Leach Metode Brine Shrimp Lethality Test (Bsit). Jurnal Laboratorium Katulistiwa. 2 (2): 67-71.

Rahmah, NI., Anggarini, S,. Pulungan, $\mathrm{MH}$. Hidayat N, Wignyanto, 2014, Pembuatan Kompos Limbah Log Jamur Tiram:Kajian Kosentrasi Kotoran Kambing Dan EM4 Serta Waktu Pembalikan, Jurnal Teknologi Pertanian, 15 (2): 59-66.

Rizal, S., Novianti, D dan Septiani, M. Pengaruh Jamur Trichoderma sp Terhadap Pertumbuhan Tanaman Tomat (Solanum lycopersicum L.) Jurnal Indobiosains. 1 (1) Edisi Februari 2019. 14-21

Siboro, E. S., E. Surya dan N. Herlina. 2013. Pembuatan Pupuk Cair dan Biogas Dari Campuran Limbah Sayuran. Jurnal Teknik Kimia USU, 2(3): 11-17.

Sihaloho, N. S., N. Rahmawati, L.A.P. Putri. 2015. Respon Pertumbuhan dan Produksi Tanaman Kedelai Varietas Detam 1 terhadap Pemberian Vermikompos dan Pupuk P. Jurnal Agroekoteknologi. 3 (4): 1591-1600.

Syahputriani, N. 2017. Pengujian Pupuk Organik Cair Limbah Buah Pepaya pada Pertumbuhan dan Produksi Tanaman Jagung Manis (Zea mays L.) (Saccharata Sturt). Skripsi. Universitas Medan Area Medan. 